\title{
A JÖVEDELMI EGYENLÖTLENSÉGEK VÁLTOZÁSAI ÉS A SZEGÉNYSÉG
}

\author{
Fábián Gergely - TAKács Péter
}

\begin{abstract}
The effects of today's economic crisis can clearly be measured on local level, for example in Nyíregyháza, Hungary as well. During the period the research was conducted the number of those workers who were let go from their jobs increased, mainly in the field of industry. In the deepest period at the onset of the crisis, between 2008 and 2009 the unemployment rate increased 3 percent, above the earlier 6 percent to 9 percent.

As a result of the crisis the income situation of the population has deteriorated. „Freezing" of income has become typical and the rate of real income loss was nearly 7 percent. The poverty rate increased by $2 \%$, so in the city it is almost $14 \%$ compared to 2008. Each indicator suggests the rise of income inequality. In addition to the tendency of becoming poor, a kind of income polarization can be seen. The tendency of falling into poverty occurs parallel with the improvement in the situation of the most wealthy groups. The group that loses in this polarization is clearly the middle class. The process has winners, those that have moved upwards and it has losers those who have slipped down.
\end{abstract}

Keywords: income inequality and polarization, poverty

DOI: $10.19055 / \mathrm{ams} .2012 .3 / 3 / 3$

A jövedelmi egyenlötlenségek változásainak mérésére számos, nemzetközi szinten standardizált mérőeszköz áll rendelkezésünkre, így követni tudjuk azok változásait a 2008 és 2010 között eltelt időszakban, mind helyi, mind hazai és nemzetközi vonatkozásban.

Kutatásunkban a háztartásokban keletkező nettó, szabad-rendelkezésü jövedelmek jellemzőit és különböző eloszlásait elemezzük, azaz figyelembe vesszük a munkavégzésböl származó, valamint az egyéb piaci jövedelmeket és a különböző szociális transzfereket is.

2008-ban Nyíregyháza városában a háztartások havi nettó jövedelmének átlaga 177.000 forint volt, a medián ${ }^{1}$ jövedelem 160.000 forint, 2010-ben 184.000 forint, il-

1 A medián olyan matematikai középérték, amely két részre osztja a mintát, s amelynél a minta 
letve változatlanul 160.000 forint. A háztartások havi nettó átlagjövedelme enyhe növekedést mutat, a medián érték változatlansága azonban már jelzi az elmúlt időszak gazdasági válságának hatását, azaz a jövedelmek „befagyását”. A növekedés nem tartott lépést az inflációval, ennek értelmében a városban reáljövedelem csökkenés mérhetö, melynek aránya közel $7 \%$.

Mivel a háztartások havi nettó összjövedelmét számos mutató alakítja, pl. a háztartásban élők száma, az aktív keresők létszáma, az eltartandók száma, stb., praktikus a jövedelmi helyzet további elemzésénél az egy főre jutó jövedelmeket figyelembe venni, mivel ezek a mutatók képezik az egyenlőtlenségekre és a szegénységre vonatkozó számítások alapját is.

A 2008-ban kapott adatok alapján külön figyelmet érdemel a városban mért átlag (69.552 forint), amely szinte alig tér el az országosan mért átlagjövedelemtől. A további vizsgálatok és összehasonlítások érdekében jövedelmi tizedeket hoztunk létre az egy före jutó jövedelmek alapján, oly módon, hogy az 1. decilis képezi a legalacsonyabb, míg a 10. decilis a legmagasabb jövedelmü csoportot.

Míg 2008-ban lényeges eltérések nem mutatkoztak az országos és a helyi adatok között, 2010-re mind a városban mért átlag, mind több decilis helyzete kedvezőtlenebb lett az országos helyzethez viszonyítva.

Az 5 legkedvezőtlenebb helyzetü decilis esetében az átlagok gyakorlatilag nem változtak, a 6., 7., 8., és 9. esetében némi növekedés tapasztalható. Egyértelmü vesztes a legmagasabb jövedelemmel rendelkező decilis, ahol romlás mérhető. A vizsgált időszakban mind országosan, mind helyben a jövedelmi egyenlötlenségek növekedésére utalnak a mutatók. A GINI ${ }^{2}$ együttható növekedése országosan $(0.288-0.292)$ és a városban is (0.285-0.290) jellemzö. Csökkent a legfelső decilis részesedése az összjövedelemből, országosan 23,6 százalékról 22,6 százalékra, ugyanez figyelhető meg Nyíregyházán is, 23,6 százalékról 22,2 százalékra.

Nyíregyházán enyhén nőtt a legalacsonyabb jövedelmű tized részesedése, ez ellentétes az országos változással, ahol csökkenés mérhető. Ugyanakkor mindenhol megfigyelhető az ötödik és a hatodik decilis részesedésének növekedése, országosan 17,7-ről 18.0 százalékra, helyi szinten 17,2 százalékról 18,6 százalékra.

Az egyenlötlenségek nemcsak a város és az ország viszonylatában mérhetőek. Jelentős eltérések figyelhetők meg Nyíregyháza egyes városkörzetei között is. (1. ábra)

A városkörzetek szerinti eloszlás alapján átlag feletti nettó háztartási jövedelmek mérhetőek 6 városrészben (Jósaváros II., Sóstó-Sóstóhegy, a Kertváros, Nyírszőlős, illetve Borbánya és Oros). Átlag körüli értékek jellemzik a belvárosi körzetet, és jóval az átlag alatti a Huszártelepet. ${ }^{3}$

elemek fele kisebb, fele nagyobb, azaz a gyakorisági eloszlást két olyan részre osztja, amely részekbe az értékek 50-50\%-a tartozik. A legfrissebb kutatásokban a jövedelmek esetében gyakrabban használt mutató, mint az átlag.

2 GINI $=$ az egyenlőtlenség olyan mértékegysége, amely 0 és 1 között vehet fel értékeket. $0=$ teljes egyenlőség, 1= teljes egyenlötlenség, azaz egy ember rendelkezik az összes jövedelemmel. A Gini-index azt méri, hogy egy adott országban, településen, stb. a jövedelmek eloszlása mennyiben tér el az abszolút egyenlőségtöl.

3 A kutatásban általunk kialakított körzetek nem minden esetben egyeznek meg a KSH által 


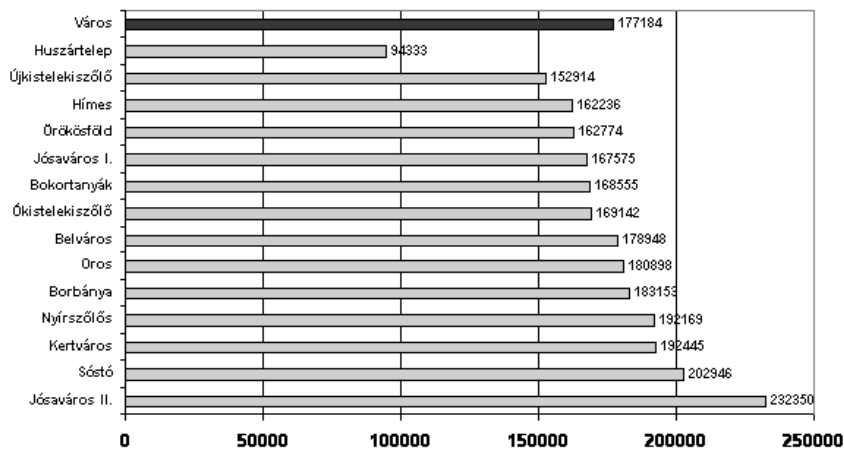

1.ábra - A háztartások nettó havi jövedelmeinek eloszlása a város egyes körzeteiben - jövedelmi átlagok, forintban, 2008. Forrás: Háztartáspanel 2010.

Szemben 2008-al a városkörzetek közötti eltérések nem mutatnak szignifikáns összefüggést 2010-ben, ami azt jelenti, hogy a válság minden körzetben hatott, illetve minden társadalmi réteget érintett. Így pl. a még mindig legkedvezőbb helyzetű városrészben (Jósaváros II) is némi jövedelemcsökkenés figyelhetö meg a két évvel ezelötti helyzethez képest. Az eredmények igen szórtak, egyes körzetekben csökkent az átlag jövedelem (pl. Nyírszőlős, Kertváros), egyes körzetekben enyhén növekedett (pl. Örökösföld, Hímes), néhányban gyakorlatilag nem változott (pl. Sóstó, Belváros).

2010-ben 7 városkörzet rendelkezett az átlagnál magasabb jövedelemmel (Jósaváros II, Ókistelekiszőlő, Sóstó, Oros, Jósaváros I, Borbánya, Nyírszőlős), amely nagyban hasonlít a korábbi helyzethez. Természetesen egyfajta állandóság is észlelhető, a legkedvezőbb helyzetben Jósaváros II, a legkedvezőtlenebben továbbra is a Huszártelep található.

Az egyenlőtlenségekre vonatkozó további mutatók szintén arról győznek meg, hogy enyhe fokban ugyan, de nőttek a jövedelmi egyenlötlenségek. (1. táblázat)

Különösen figyelemkeltő a p10/p50 mutató értékének csökkenése, 51 százalékról 48 százalékra, ami egyértelmüen a rosszabb jövedelmü helyzetbe tartozók pozíciójának enyhe romlását mutatja, igaz a csökkenés mértéke alacsonyabb volt, mint országo san. (2. táblázat)

Egyes csoportok esetében figyelhető meg eltérés az országos helyzethez viszonyítva. A városban alacsonyabb a kifejezetten jómódban élők aránya, illetve magasabb az alsó középréteghez sorolhatók száma. Ez utóbbi csoport azért érdemel figyelmet, mert esetükben jellemzö az, hogy bármilyen váratlan esemény (pl. állás elvesztése, jövede-

(elsősorban a népszámlálás lebonyolításához) alkalmazott lehatárolásokkal, ugyanakkor számos mutató megerösíti (ilyen pl. a lakosok iskolázottsága) egyes körzetek kedvezö, illetve kedvezőtlen helyzetét, pl. a Jósaváros, vagy a Huszártelep esetében. 
lem csökkenése, betegség) bekövetkeztekor könnyen lecsúszhatnak a szegénynek nevezett csoportba, mivel általában nem rendelkeznek olyan jövedelmi - vagyoni tartalékokkal, amelyekkel ezt meg tudnák akadályozni. (3. táblázat)

\begin{tabular}{|l|c|c|}
\hline Mutatók & Nyíregyháza, 2008 & Nyíregyháza, 2010 \\
\hline $\mathrm{p} 10 / \mathrm{p} 50$ & 0,51 & 0,48 \\
\hline $\mathrm{p} 90 / \mathrm{p} 50$ & 1,68 & 1,7 \\
\hline $\mathrm{p} 90 / \mathrm{p} 10$ & 3,30 & 3,55 \\
\hline $\mathrm{S} 10 / \mathrm{S} 1$ & 7,2 & 6,6 \\
\hline $\mathrm{S} 1$ & 3,1 & 3,8 \\
\hline $\mathrm{S} 5+\mathrm{S} 6$ & 17,2 & 18,6 \\
\hline S10 & 23,6 & 22,2 \\
\hline Robin Hood index & 20,0 & 20,0 \\
\hline Éltető Frigyes index & 2,21 & 2,25 \\
\hline GINI & 0.285 & 0.290 \\
\hline
\end{tabular}

1. táblázat - A jövedelmi egyenlőtlenségek egyes mutatóinak változása a városban, 2008-2010. Forrás: Háztartáspanel 2010.a mutatók magyarázatát lásd a tanulmány végén.

\begin{tabular}{|l|c|c|}
\hline & Magyarország & Nyíregyháza \\
\hline $\begin{array}{l}\text { „Jómódúak” } \\
\text { (akiknek a medián kétszeresénél több a jövedelme) }\end{array}$ & 8 & 5,4 \\
\hline „Felső-középréteg” (a medián 120-200 \%-a) & 27 & 26,5 \\
\hline „Középréteg” (a medián 80-120 \%-a) & 31 & 29,1 \\
\hline „Alsó középréteg” (a medián 50-80 \%-a) & 22 & 27,6 \\
\hline „Szegények” (50 \% alatt) & 12 & 11,4 \\
\hline
\end{tabular}

2. táblázat - Empirikus becslés az egyes jövedelmi kategóriák létszámára, 2010 (az egy före jutó jövedelem medián-értékének százalékában meghatározott csoportok, \%). Országos adatok: 2009. Forrás: TÁRKI, 2010.

A vizsgált időszakban bekövetkezett változás mérsékelt jövedelmi polarizációt jelez, azaz nőtt a szegények és a jómódúak csoportjának aránya is, elsődlegesen a középréteg „kárára”. A szegénységben élők aránya erőteljesebb növekedést mutat, mint a jómódban élők csoportjánál megfigyelhető emelkedés. 
Amennyiben a fenti számításokat az Unióban, euróban mért mediánjövedelem függvényében végezzük el, néhány újonnan csatlakozott ország (köztük Magyarország) jövedelmi lemaradása, jövedelmi szegénysége válik markánsan megfigyelhetővé, hiszen Lettországban 68, Litvániában 63, Lengyelországban 60, Görögországban, Szlovákiában és Magyarországon 50 százalékos szegénységi rátával kell számolnunk. A sorban bennünket követő Portugáliában a szegénységben élők aránya már csak 28 százalékos. A legkedvezőbb helyzet a skandináv országokban, szomszédaink közül pedig Ausztriában mérhető, ahol a ráta 1-2 százalékos (Lelkes et al, 2009).

\begin{tabular}{|l|c|c|}
\hline & Nyíregyháza, 2008 & Nyíregyháza, 2010 \\
\hline $\begin{array}{l}\text { „Jómódúak” (akiknek a medián kétszeresénél } \\
\text { több a jövedelme) }\end{array}$ & 4,6 & 5,4 \\
\hline „Felső-középréteg” (a medián 120-200 \%-a) & 25,2 & 26,5 \\
\hline „Középréteg” (a medián 80-120 \%-a) & 32,8 & 29,1 \\
\hline „Alsó középréteg” (a medián 50-80 \%-a) & 28 & 27,6 \\
\hline „Szegények” (50 \% alatt) & 9,4 & 11,4 \\
\hline
\end{tabular}

3. táblázat - Empirikus becslés az egyes jövedelmi kategóriák létszámának változására, 2008-2010 (az egy före jutó jövedelem medián-értékének százalékában meghatározott csoportok, \%). Forrás: Háztartáspanel 2010.

Kiemelendő, hogy szignifikáns eltérés mutatkozik az egyes csoportok esetében a háztartásnagyság tekintetében. Míg az átlagos háztartásnagyság a városban 2,98fö, addig az első és a második decilisek esetében 4,03, illetve 3,62 fö. Ezzel szemben a legkedvezőbb helyzetü 9 . és 10 . deciliseknél 2,29 , illetve 2,02 fö.

A magasabb létszámú háztartásnagyság az esetek döntő részében a háztartásban élő és 18 évesnél fiatalabb korosztályokból adódik. (4. táblázat)

\begin{tabular}{|l|c|c|}
\hline & Háztartás átlagos létszáma, 2008 & Háztartás átlagos létszáma, 2010 \\
\hline Szegények & 4,03 & 4,03 \\
\hline Felső középréteg & 3,43 & 3,51 \\
\hline Középréteg & 2,73 & 2,90 \\
\hline Alsó középréteg & 2,15 & 2,30 \\
\hline Jómódúak & 1,84 & 1,89 \\
\hline
\end{tabular}

4. táblázat - A háztartások átlagos létszáma az egyes társadalmi csoportokban, 2008-2010 (átlagértékek, fö). Forrás: Háztartáspanel 2010.

Ezt erősíti meg az a tény is, hogy a gyermeket nevelő háztartások általában kedvezőtle nebb helyzetben vannak a gyermektelenekkel szemben. (2. ábra) 


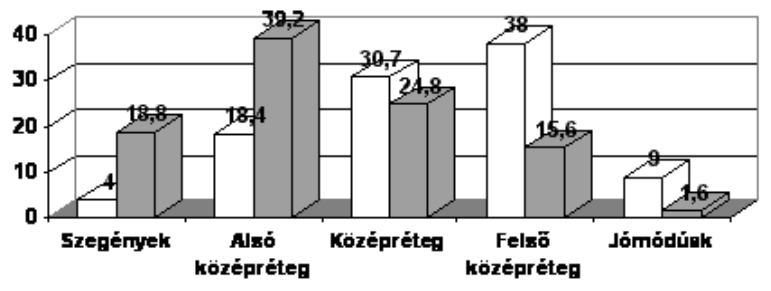

口Gyermektelen háztnrtís qGyermekes híztnrtís

2. ábra - A gyermekes és gyermektelen háztartások megoszlása az egyes társadalmi csoportokban, 2010. (\%). Forrás: Háztartáspanel 2010.

A gyermeket nevelő háztartások nagyobb valószínűséggel tartoznak a kedvezőtlenebb jövedelmủ csoportokba, mint a gyermektelen háztartások.

A Nyíregyházán bekövetkezett változás, azaz a jövedelmi polarizálódás nem lokális jelenség, a város gyakorlatilag „lekövette” a hazai tendenciákat. Magyarországon a 2007 és 2009 közötti időszakban 1 százalékponttal nőtt a jómódúak, 2 százalékponttal a felső középréteg és a szegények relatív aránya a népességen belül, míg 5 százalékponttal csökkent a középrétegé (TÁRKI, 2010).

Bár a fenti számítások már jelzik a szegénység növekedését, érdemes áttekinteni annak alakulását az ún. laekeni indikátorok függvényében is. A korábbi évtizedekben végzett szegénységszámítások általában az adott országra jellemző átlagjövedelmet vették figyelembe, s annak valamilyen százalékos értékében (40, 50, illetve 60) állapították meg a szegénységi küszöböt. A laekeni indikátorokhoz sorolt mutatók kidolgozásáról 2001 decemberében, az EU Bizottságának laekeni ülésén született határozat, melynek célja a jövedelmi szegénység és kirekesztettség nemzetközi szinten is összehasonlítható mérése. Az elsődleges indikátorokhoz tartozik a szegénységi arány megállapítása, amely a medián ekvivalens jövedelem $60 \%$-ánál kevesebb jövedelemmel rendelkező háztartásokban élő személyek arányát jelenti. Az ekvivalens jövedelem megállapításához figyelembe kell venni a méretgazdaságosságot is, tehát azt, hogy bizonyos szükségletek (pl. lakásfenntartás) nem a személyekhez, hanem a háztartás egészéhez kötődnek, így szükségessé vált fogyasztási egységskála meghatározására is. Jelenleg két egységskála használata a jellemző (OECD1-skála és OECD2-skála), melyek közül az OECD2-skála, illetve a skála felhasználásával meghatározott szegénységi arány tekinthetö „hivatalosnak” (KSH, 2006). ${ }^{4}$ (5. táblázat)

4 Az ún. OECD1-skála a háztartás első felnőtt tagjához 1-es, a további felnőtt tagokhoz 0,7-es, a gyermekekhez 0,5-es értéket társít, míg az OECD2-skála a további felnőtt tagokhoz 0,5-es, a gyermekhez 0,3-es súlyt rendel. Ebből adódóan az OECD1-skála a kisebb (jellemzően nyugdíjas), az OECD2- skála a nagyobb (többgyermekes) háztartások szegénységi arányát mutatja magasabbnak. Az OECD1-röl az OECD2-re történő uniós áttérés fő indoka az volt, hogy a lakásfenntartási kiadások aránya a fejlett nyugati országokban az összfogyasztáson belül jelentősen megnőtt. 


\begin{tabular}{|l|c|c|}
\hline & Nyíregyháza & Ország \\
\hline OECD1-skála & 15,7 & 14,8 \\
\hline OECD2-skála & 13,8 & 14,0 \\
\hline
\end{tabular}

5. táblázat - Szegénységi ráták Nyíregyházán és Magyarországon, 2010. (\%). Országos adatok: 2009. Forrás: TÁRKI, 2010.

Az OECD1-skála alapján valamivel magasabb szegénység mérhető a városban, míg a hivatalosnak tekinthető OECD2-skála szerint eltérés gyakorlatilag nincs.

Az OECD II. skála alapján végzett számítás is azt erősíti meg, hogy az elmúlt 2 évben 2 százalékponttal nőtt a szegénység, mind országosan, mind lokálisan.

Hasonló tendencia figyelhető meg az Unió területén is, hiszen míg 2007-ben 79 millió ember élt szegénységben a 27 tagországban, addig 2008-ban már 81 millió (17 \%), a növekedés mértéke hasonló ütemü, mint hazánkban. Az egyes tagországok esetében azonban lényeges eltérések figyelhetők meg. Számos korábbi tagországban a növekedés üteme kisebb (jellemzően 1 százalék alatti), míg pl. három új tagország esetében jóval az átlag feletti. Bulgáriában hat, Lettországban és Romániában négy százalékponttal nőtt a szegények aránya (Eurostat, 2010). (6. táblázat)

\begin{tabular}{|l|l|l|l|}
\hline Románia & $22,4^{*}$ & Írország & $15,0^{*}$ \\
\hline Bulgária & $21,4^{*}$ & Belgium & $14,6^{* *}$ \\
\hline Lettország & $21,3^{* *}$ & Luxemburg & $14,5^{* *}$ \\
\hline Spanyolország & $20,7^{* *}$ & Magyarország & $14,0^{*}$ \\
\hline Litvánia & $20,2^{* *}$ & Nyíregyháza & $14,0^{* *}$ \\
\hline Görögország & $19,7^{*}$ & Dánia & $13,1^{*}$ \\
\hline Olaszország & $18,4^{*}$ & Finnország & $13,1^{* *}$ \\
\hline Portugália & $17,9^{*}$ & Franciaország & $12,9^{*}$ \\
\hline Egyesült Királyság & $17,3^{*}$ & Svédország & $12,9^{* *}$ \\
\hline Lengyelország & $17,1^{*}$ & Szlovénia & $12,7^{* *}$ \\
\hline Ciprus & $16,2^{*}$ & Ausztria & $12,1^{* *}$ \\
\hline Észtország & $15,8^{* *}$ & Hollandia & $11,1^{*}$ \\
\hline Németország & $15,6^{* *}$ & Szlovákia & $11,0^{*}$ \\
\hline Málta & $15,5^{* *}$ & Csehország & $9,0^{* *}$ \\
\hline
\end{tabular}

6. táblázat - Szegénységi ráták az Európai Unió tagországaiban, 2009-2010 (\%). Forrás: Eurostat, EU-SILC adatbázis, és Háztartáspanel. *2009; **2010 
Magyarország és Nyíregyháza város helyzete viszonylag kedvezőnek mondható, ugyanakkor miközben a mérés mindenfajta nemzetközi összehasonlításra alkalmas, általában nem mond semmit a szegénység „minőségéröl”. ${ }^{5}$ (7. táblázat)

\begin{tabular}{|l|l|l|}
\hline & Nyíregyháza & Ország \\
\hline 1 személyes 65 felett & 3,1 & 5,6 \\
\hline Pár, mindkettő 65 alatt & 8,4 & 11,1 \\
\hline Pár 1 gyermekkel & 12,5 & 10,9 \\
\hline Pár 2 gyermekkel & 18,3 & 18,8 \\
\hline Pár 3 gyermekkel & 22,2 & 25,4 \\
\hline Egyedül nevelő & 35,8 & 31,4 \\
\hline
\end{tabular}

7. táblázat - Szegénységi ráták az egyes háztartástípusokban Nyíregyházán és Magyarországon, 2010. (\%). Országos adatok: 2009. Forrás: TÁRKI, 2010.

Több háztartástípus esetében mérhetök eltérések, bár ezek mértéke nem mondható jelentősnek. A városban valamivel kedvezőbb helyzet tapasztalható a gyermektelen háztartások esetében, illetve a 3 gyermeket nevelök körében. Általános tendencia azonban, hogy a gyermekek számával nő a szegénység kockázata is, és különösen veszélyeztetettek a gyermeküket egyedül nevelök.

Ezt erősíti meg az az eredmény is, mely szerint (dichotóm módon definiálva a háztartásokat) a gyermeket nevelő háztartások esetében mért szegénységi ráta $18 \%$, szemben a gyermektelen háztartásokkal, ahol ez az arány $10.7 \%$.

Hazánkban közismert tény, hogy az iskolázottság meghatározó tényező a szegénység esetében, ez a városban is jellemző. (3. ábra)

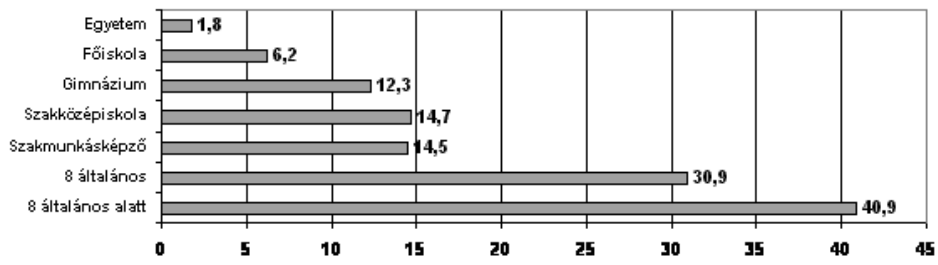

3. ábra - Szegénységi ráták az iskolai végzettség függvényében, a háztartásfők körében 2010. (\%). Forrás: Háztartáspanel 2010.

Bár nem igazán szignifikáns az eredmény, a nők körében magasabb a szegények aránya.

5 A számítások ebben az esetben az adott országra jellemző jövedelmi viszonyokból indulnak ki, és azok eloszlását vizsgálják. Ezek alapján Magyarország helyzete már 2007 és 2008 között is viszonylag kedvező volt. 
Szignifikáns összefüggés mutatható ki a munkavégzés tekintetében is, hazánkban és nemzetközi szinten is igaz, hogy a munkával rendelkezök körében jóval alacsonyabb ráták mérhetőek, mint a munkanélküliek esetében. (4. ábra)

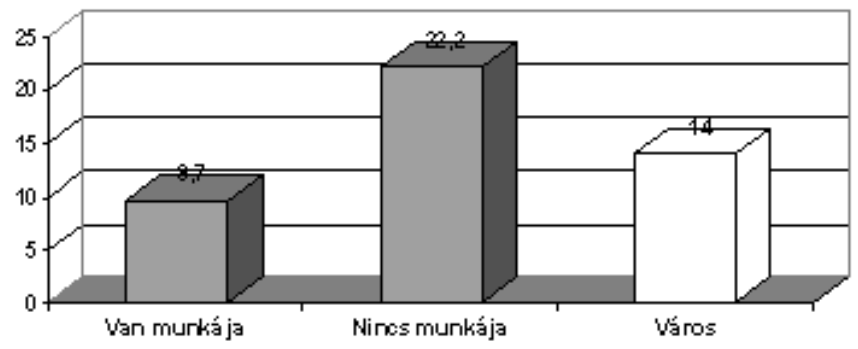

4. ábra - A szegénység aránya a munkával rendelkezők, illetve nem rendelkezők körében, 2010 (\%). Forrás: Háztartáspanel 2010.

A fent említett összefüggés Nyíregyházán is érvényes, hiszen az inaktívak rátája 8 százalékkal haladja meg a városi átlagot. Ugyanakkor figyelmet érdemel az a tény, hogy közel 10 százalékos ráta mérhető azok körében, akik dolgoznak, tehát rendelkeznek munkajövedelemmel. Öket, az utóbbi évek kutatásai alapján nevezzük dolgozó szegényeknek. A ráta közel áll az unióban mérthez, ahol a tagországok összesített rátája $8 \%$. Ahogyan arra az EU-ban 2007-ben végzett kutatás rámutat: „Általánosan elfogadott tény, hogy ha valaki foglalkoztatásban áll, az nagymértékben csökkenti a szegénység kockázatát. Az Európai Unióban azonban 2007-ben a munkavállaló népesség 8\%-a a „, dolgozó szegények” kategóriájába esett abban az értelemben, hogy jövedelme mértéke a nemzetre jellemzö mediánérték 60\%-a alá esik. Az arány jelentösen különbözik az egyes országok és társadalmi csoportok tekintetében. A dolgozó szegények kérdését a legtöbb országban sem a kormány, sem a szociális partnerek nem kezelik politikai prioritásként, jóllehet ez a téma a szegénység és a társadalmi kirekesztés elleni általános politikában gyakran szerepel ". 6

A foglalkoztatottak szegénységi rátája igen különböző az egyes országokban, így pl. Görögországban (14\%), Lengyelországban (12\%), Spanyolországban (11\%), valamint Olaszországban, Lettországban és Portugáliában (egyaránt 10\%) a legmagasabb, míg Csehországban (3\%), Belgiumban, Dániában és Máltán (egyaránt 4\%) a legalacsonyabb.

2007-ben hazánkban a dolgozó szegények aránya $6 \%$ volt, feltételezhető, hogy ez az arány a válság hatására növekedett.

Ahogyan azt a nemzetközi kutatás kiemeli: „A fö tényezök, amelyek alapján megitélhetö, hogy egy ember nagy valószínüséggel a dolgozó szegények kategóriájába esik-e, többek között a személyes vonatkozások (nem, kor és képzettség), a háztartás jellemzöi (egyedül élö, a háztartásban eltartott gyermekek élnek/nem élnek), valamint

6 A nemzetközi adatok forrása: Dolgozó szegények Európában, 2010. 
a foglalkozási tényezők (egy évben hány hónapig áll alkalmazásban, beosztás, teljes vagy részmunkaidös munka, a munkaszerzödés típusa). A kutatás szerint a férfiak és a fiatalok különösen kiszolgáltatottak, az alacsony képzettségi szint pedig - a magas képzettségi szintü munkavállalókkal összehasonlitva - mintegy ötszörösére növeli annak kockázatát, hogy valaki a dolgozó szegények kategóriájába esik-e”.

Érdemes megvizsgálni, hogy mennyire érvényesülnek ezek a hatások a városban. A személyes vonatkozások esetében a nemek között nincs szignifikáns eltérés, sőt az életkor sem befolyásoló tényező, az iskolai végzettség azonban már igen. (5. ábra)

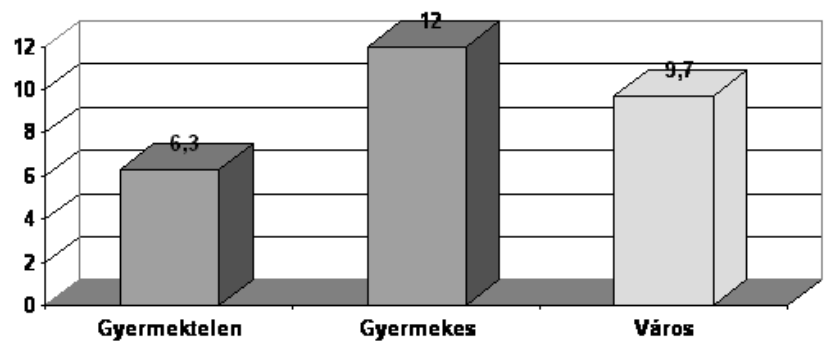

5. ábra - A dolgozó szegények aránya a végzettség függvényében, 2010 (\%).

Forrás: Háztartáspanel 2010.

A végzettség a városban is erőteljesen befolyásoló tényező. Szignifikánsan befolyásolja a helyzetet, ha a háztartásban van kiskorú gyermek. (6. ábra)

A foglalkoztatás jellege a városban is döntő tényezö, az ún. atipikus formákban foglalkoztatottak körében magasabb ráták jellemzők. (7. ábra)

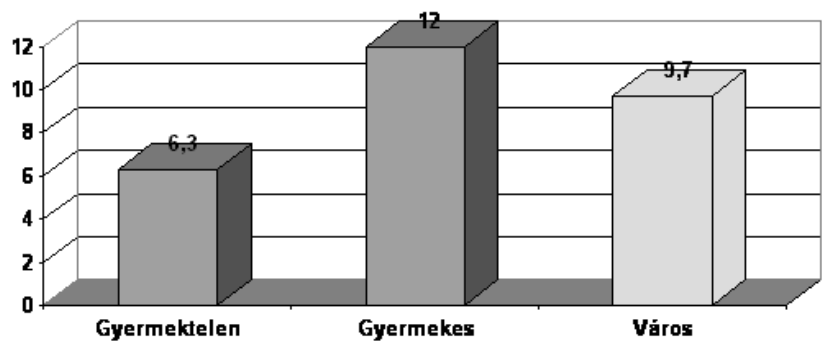

6. ábra - A dolgozó szegények aránya a gyermekes, illetve a gyermektelen háztartásokban, 2010 (\%). Forrás: Háztartáspanel 2010. 


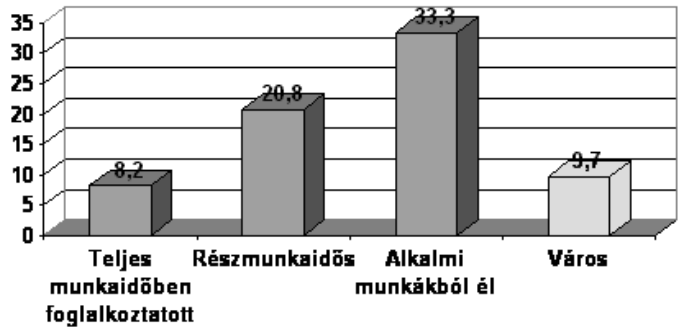

7. ábra - A dolgozó szegények aránya az egyes foglalkoztatási formák függvényében, 2010 (\%). Forrás: Háztartáspanel 2010.

A dolgozó szegények csoportja alapvetően a három legalacsonyabb jövedelemmel rendelkező decilishez sorolható. Összességében megállapítható, hogy a városban is „,sokarcú” szegénységgel kell számolni, nemcsak olyan csoportokkal, akik jellemzően aluliskolázottak, nem rendelkeznek szakképzettséggel, vagy az már elavult, és jellemzően szociális transzferekből élnek meg, ide tartoznak olyan csoportok is, akik rendelkeznek munkával, munkajövedelemmel.

A jövedelmi helyzet romlásának egy érdekes mutatója, milyen gyakran és milyen területeken kerülnek a háztartások likviditási nehézségekbe. 2008-ban a nyíregyházi háztartások 17,3 százaléka került a felmérést megelőző évben olyan helyzetbe, hogy nem tudott valamit kifizetni, 2010-ben ez az arány már 21,7 \% volt. Az alacsonyabb jövedelmü csoportoknál ezek jellemzően közüzemi számlák voltak, azon belül is tipikusan a fütéssel és villannyal kapcsolatos kiadások, de természetesen ide tartoznak a különböző hiteltörlesztések is. A pénzzavar alapvetően szinte minden társadalmi csoport esetében előfordul. A szegények körében a leggyakoribb, míg a jómódban élők esetében egyre ritkább. (8. ábra)

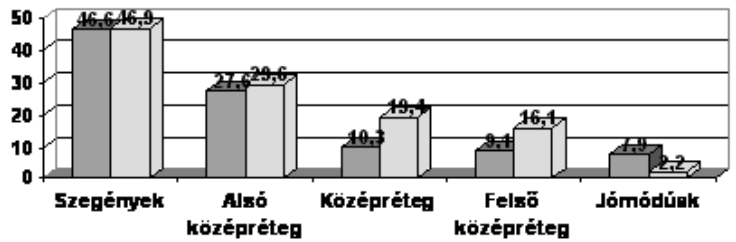

2008 $\square 2010$

8. ábra - Háztartások aránya, amelyeknél előfordult az elmúlt évben, hogy valamit nem tudtak kifizetni, 2008-2010. (\%). Forrás: Háztartáspanel 2010. 
Az adatokból jól látszik, hogy az elmúlt két évben kizárólag a jómódúak körében csökkent a havi pénzzavart jelző háztartások aránya, növekedés szinte minden csoportban bekövetkezett, még a viszonylag jobb körülmények között élö középrétegek körében is.

A háztartások jövedelmi - vagyoni helyzetének egy másik mutatója, hogy milyen tartós fogyasztási cikkekkel rendelkeznek. (8. táblázat)

\begin{tabular}{|l|r|r|l|r|r|}
\hline & 2008 & 2010 & & 2008 & 2010 \\
\hline Hủtőszekrény & 98,3 & 99,3 & Személygépkocsi & 57,3 & 64,7 \\
\hline Színes televízió & 98,2 & 98,8 & Videomagnó & 56,5 & 61,9 \\
\hline Mosógép & 96,4 & 97,6 & Internet hozzáférés & 47,8 & 63,3 \\
\hline Mobiltelefon & 89,3 & 91,5 & Digitális fényképezőgép & 43,7 & 52,5 \\
\hline Mikrohullámú sütő & 83,7 & 93,0 & Szélessávú Internet hozzáférés & 36,3 & 47,0 \\
\hline Vezetékes telefon & 62,3 & 64,9 & Házi mozi rendszer & 21,2 & 24,3 \\
\hline DVD lejátszó & 61,1 & 68,9 & Mosogatógép & 19,8 & 25,7 \\
\hline Számítógép & 59,0 & 73,2 & Egyéb ingatlan & 13,0 & 10,4 \\
\hline
\end{tabular}

8. táblázat - A háztartások felszereltsége - tartós fogyasztási javak aránya, 2008-2010 (\%). Forrás: Háztartáspanel 2010.

A jövedelmi adatok tükrében paradox helyzetnek tünik, de 2008-hoz képest több területen javult a háztartások felszereltsége, igaz ezek az eszközök dominánsan azok, amelyek ma már nem számítanak luxuscikknek, illetve azt is figyelembe kell venni, hogy a jómódúak és a felső középosztály aránya is növekedett a városban. A drágább, bizonyos fokig még luxusterméknek számító eszközök (pl. házimozi, mosogatógép) aránya továbbra is alacsony. Csökkenés egy területen látható, a háztartások egy része „megszabadult” egyéb ingatlanától (pl. üdülő, telek) vélhetően a gazdasági válság hatásainak ellensúlyozására.

Amennyiben a napjainkban egyre fontosabbá váló IKT (Információs és Kommunikációs technológiai) eszközök jelenlétét vizsgáljuk, a nyíregyházi háztartások ellátottsága az esetek egy részében megegyezik az országos ellátottsági arányokkal, egy részében pedig kedvezőbb. Jelentősebb eltérések mérhetőek a város és az Észak-alföldi régió összevetésében, azzal a megjegyzéssel, hogy a régió helyzete is kedvezőbb lett 2008-hoz képest. (9. táblázat)

Ennek ellenére mind az országos, mind a helyi arányok elmaradnak az unió 27 tagországára jellemző adatoktól, hiszen 2009-ben az európai háztartások 65 százaléka rendelkezett Internet hozzáféréssel, illetve 56 százaléka szélessávú Internet hozzáféréssel.

Hazánk (és így a város) mindössze 10 országot előz meg ebben a tekintetben (szélessávú Internet-hozzáférés), igaz ezek között nemcsak kelet-európai országok találhatóak (pl. Románia, Bulgária, Csehország), hanem régi tagországok is (pl. Olaszország, Portugália).

A kelet-európai országok közül nagyon hasonló arányok mérhetőek Lengyelország tekintetében, ugyanakkor hazánknál jóval kedvezőbb a helyzet Észtországban (62 \%) és Szlovéniában (56 \%). Az elmúlt időszak fejlődése azonban igen dinamikus, hiszen 
két évvel ezelőtt több kelet-európai ország megelözött bennünket (pl. Szlovákia), akik ma már sereghajtók az unióban.

A jövő szempontjából igen bíztató, hogy a gyermekkorú személy jelenléte a háztartásban erőteljesen befolyásolja az IKT-eszköz-ellátottságot, és ebből következően a használatot. Ez a jelenség helyi szinten és országosan is jellemzö. (10. táblázat)

\begin{tabular}{|l|l|l|l|l|l|l|}
\hline & \multicolumn{2}{|l|}{ Ország } & \multicolumn{2}{l|}{ Észak-Alföld } & \multicolumn{2}{l|}{ Nyíregyháza } \\
\hline & 2008 & 2010 & 2008 & 2010 & 2008 & 2010 \\
\hline Vezetékes telefon & 61,0 & 57,0 & n.a. & 48,7 & 62,3 & 64,9 \\
\hline Mobiltelefon & 88,0 & 90,0 & 86,4 & 89,2 & 89,3 & 91,4 \\
\hline Számítógép & 59,0 & 63,0 & 52,0 & 68,7 & 59,0 & 72,8 \\
\hline Internet hozzáférés & 48,0 & 55,0 & 40,0 & 46,2 & 47,8 & 62,8 \\
\hline Szélessávú Internet hozzáférés & 42,0 & 51,0 & 35,5 & 43,0 & 36,3 & 46,2 \\
\hline
\end{tabular}

9. táblázat - A háztartások fontosabb IKT eszközökkel való ellátottsága - 2008-2010 (\%). Országos adatok forrása: KSH, 2010.

\begin{tabular}{|c|c|c|c|c|}
\hline & Ország & & Nyíregyháza & \\
\hline & $\begin{array}{l}\text { Gyermekkorú } \\
\text { taggal nem } \\
\text { rendelkezö } \\
\text { háztartás }\end{array}$ & $\begin{array}{l}\text { Gyermekkorú } \\
\text { taggal } \\
\text { rendelkező } \\
\text { háztartás }\end{array}$ & $\begin{array}{l}\text { Gyermekkorú } \\
\text { taggal nem } \\
\text { rendelkezö } \\
\text { háztartás }\end{array}$ & $\begin{array}{l}\text { Gyermekkorú } \\
\text { taggal } \\
\text { rendelkező } \\
\text { háztartás }\end{array}$ \\
\hline Mobiltelefon & 88 & 97 & 84,7 & 97,4 \\
\hline Számítógép & 55 & 84 & 57,6 & 88,8 \\
\hline $\begin{array}{l}\text { Internet } \\
\text { hozzáférés }\end{array}$ & 48 & 73 & 46,4 & 81,3 \\
\hline $\begin{array}{l}\text { Szélessávú } \\
\text { Internet } \\
\text { hozzáférés }\end{array}$ & 44 & 68 & 31,4 & 60,4 \\
\hline
\end{tabular}

10. táblázat - A háztartások IKT-eszközökkel való ellátottsága a háztartás típusa szerint, 2010 (\%). Országos adatok forrása: KSH, 2010.

Az információ és kommunikációs technológiák birtoklásából és használatából fakadó egyenlötlenségek vizsgálatához érdemes két csoportra osztani a háztartásokat, modern „info-kommunikációs” háztartásokra, illetve azokra, akik ezekkel az eszközökkel nem, vagy csak részlegesen rendelkeznek. Modern kommunikációs háztartásoknak tekintettük azokat, amelyek egyszerre rendelkeznek vezetékes telefonnal, mobiltelefonnal, számítógéppel és internetkapcsolattal. A nyíregyházi háztartások 35,6 százaléka tekinthető ebből a szempontból „modern kommunikációs háztartásnak”. 
A városban jelentősebb területi egyenlőtlenségek figyelhetők meg ebben a tekintetben is. (9. ábra)

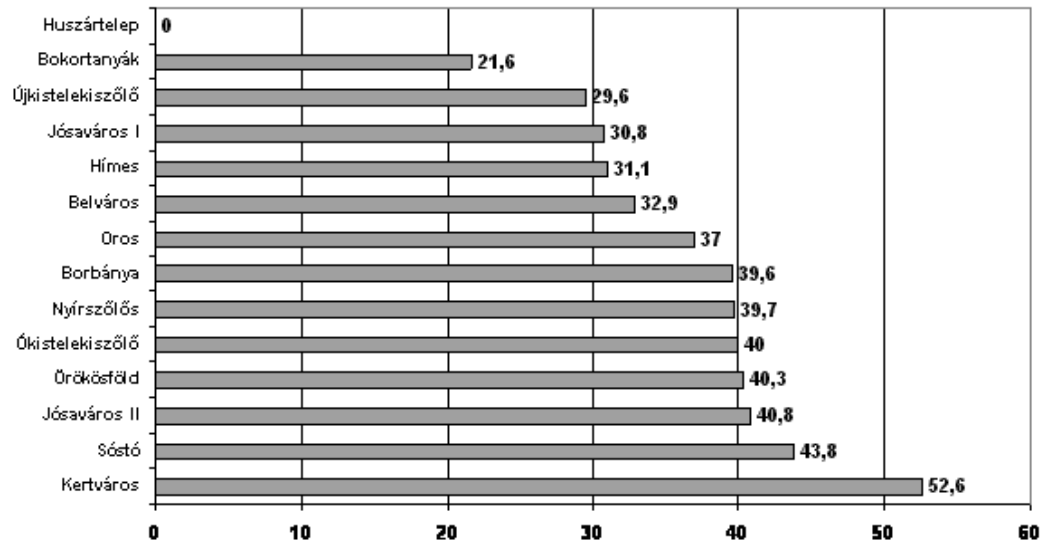

9. ábra - A modern kommunikációs háztartások aránya az egyes városkörzetekben, 2008. (\%). Forrás: Háztartáspanel 2010.

A legkedvezőbb helyzetủ városrészek (Kertváros, Sóstó, Jósaváros II) előnye ebben a tekintetben is jellemző, illetve egyes városrészek lemaradása (Huszártelep, Bokortanyák, Újkistelekiszőlő) tipikus. Ugyanakkor néhány esetben (Örökösföld, Ókistelekiszőlő) jóval kedvezőbb helyzet mérhető, mint azt a jövedelmi adatok ,indokolnák”. Ez az eredmény arra is utal, hogy bár a jövedelmi helyzet nyilvánvalóan meghatározó, mégsem az egyetlen befolyásoló tényező az IKT eszközök esetében. Erőteljes befolyással bír ebből a tekintetből a lakosok végzettsége, és bizonyos fokig az életkor. (10. és 11. ábra)

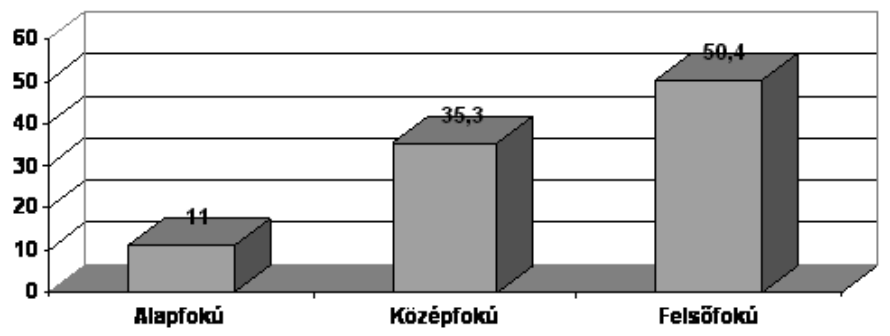

10. ábra - A modern kommunikációs háztartások aránya a különböző végzettséggel rendelkezők függvényében, 2008. (\%). (Forrás: Háztartáspanel 2010. 


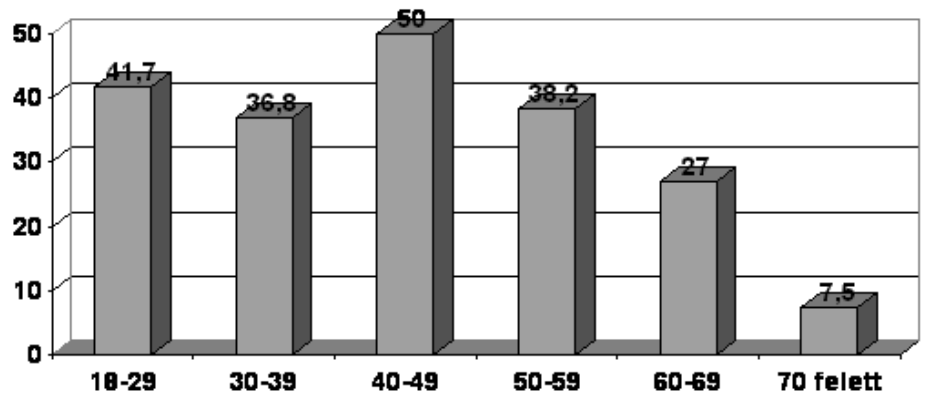

11. ábra - A modern kommunikációs háztartások aránya az egyes életkori csoportok függvényében, 2008. (\%). Forrás: Háztartáspanel 2010.

A fiatal, illetve középkorúak körében mérhetőek a legmagasabb arányok, az 50 év feletti korosztályok esetében már jelentős csökkenés tapasztalható. ${ }^{7}$

Összességében megállapítható, hogy 2008 és 2010 között a városban alapvetően reáljövedelem csökkenés következett be, melynek mértéke közel 7 százalékos volt, jellemzővé vált a jövedelmek „,befagyása”.

A városban mért „hivatalos” szegénységi ráta közel $14 \%$-os, ami 2 százalékpontos növekedést jelent 2008-hoz képest. Minden mutató a jövedelmi egyenlötlenségek növekedésére utal, azzal, hogy a városban nemcsak elszegényedés figyelhető meg, sokkal inkább jellemző egyfajta jövedelmi polarizálódás, azaz egyszerre jellemző tendencia az elszegényedés, illetve ezzel párhuzamosan a legtehetősebb csoportok helyzetének egyfajta javulása is. A polarizálódás egyértelmüen a középréteg kárára következett be, a folyamatnak vannak nyertesei, akik fölfelé mozdultak el, és vannak vesztesei, akik lecsúsztak. A szegénység a városban is sokarcú, azaz nemcsak azokra a csoportokra kell gondolnunk, akik jellemzően inaktívak, munkanélküliek, hanem olyanokra is, akik a dolgozó szegények körébe tartoznak.

Érdemes azonban azt is kiemelni, hogy a TÁRKI kutatásainak eredményeit figyelembe véve a város gyakorlatilag „lekövette” az országos tendenciákat, a fent leírt változások jellemzik hazánkat is. Szintén kiemelésre érdemes, hogy a Magyarországon és Nyíregyházán mért egyenlötlenségek nemzetközi összehasonlításban közepes differenciákra utalnak.

7 Talán meglepő lehet (különösen) a 60-69 év közöttiek körében mért arány, ugyanakkor az országos felmérések eredményei is arra utalnak, hogy az idősek körében 2005 óta jelentősebben bővült a számítógépet használó, és internetezők aránya, az 55-64 éves korosztály esetében 20 százalékról közel 40-re, míg a 65-74 évesek korcsoportjában néhány százalékról közel 20 százalékra (KSH, 2009). 
MELLÉKLET - A jövedelmi egyenlőtlenségekre vonatkozó mutatók:

p10/p50 = a mutatószám az alsó jövedelmi tized felső határpontját viszonyítja a mediánhoz. p90/p50 = a mutatószám a legfelső jövedelmi tized alsó határát viszonyítja a mediánhoz. p90/p10 = a mutatószám az alsó jövedelmi tized felső határpontját viszonyítja a felső jövedelmi tized alsó határpontjához.

$\mathbf{S 1 0 / S 1 ~ = ~ a ~ l e g a l s o ́ ~ d e c i l i s ~ e ́ s ~ a ~ l e g f e l s o ̋ ~ d e c i l i s ~ a ́ t l a g j o ̈ v e d e l m e ́ n e k ~ h a ́ n y a d o s a , ~ a z a z ~}$ hányszorosa a legfelső decilis átlagjövedelme a legalsónak. $\mathbf{S 1}=$ a legalsó decilis részesedése az összes jövedelemböl, százalékban. S5+S6 = a középen lévő decilisek részesedése az összes jövedelemböl, százalékban.

$\mathbf{S 1 0}=$ a legfelső decilis részesedése az összes jövedelemből, százalékban.

Robin Hood index $=$ az egyenlőtlenségek általános szintjének kimutatására szolgál. Kiindulópontja, hogy teljes egyenlőség esetén a jövedelmek egyenletesen oszlanak meg az egyének között, azaz mindegyik jövedelmi tizedbe a népesség összjövedelmének 10-10 százaléka esik. A Robin Hood-index ettől az egyenletes megoszlástól való eltérést mutatja: a 10 százaléknál nagyobb jövedelemaránnyal rendelkező decilisek 10 százalék feletti százalékrészeinek összegeként számolható ki. Másként megfogalmazva, ha akadna egy Robin Hood, aki a gazdagoktól elvett javakat a szegények számára szeretné újraosztani, akkor a szóban forgó index azt jelentené, hogy maximum mekkora hányadot kellene átcsoportosítani, hogy kiegyenlítődjenek a jövedelmi egyenlötlenségek.

Éltető Frigyes index $=$ az átlag feletti és az átlag alatti jövedelmek hányadosa, azaz az átlag fölötti jövedelmek átlagát az átlag alatti jövedelmek átlagával vetjük össze. Teljes jövedelemegyenlöség esetén a mutató értéke 1, ennél nagyobb érték a jövedelmi olló nagyságát mutatja.

GINI = az egyenlőtlenség olyan mértékegysége, amely 0 és 1 között vehet fel értékeket. $0=$ teljes egyenlőség, $1=$ teljes egyenlőtlenség, azaz egy ember rendelkezik az öszszes jövedelemmel. A Gini-index azt méri, hogy egy adott országban, településen, stb. a jövedelmek eloszlása mennyiben tér el az abszolút egyenlőségtől.

\section{IRODALOM}

1. Európai Alapítvány az Élet-és Munkakörülmények Javításáért (2010): Dolgozó szegények Európában. Budapest.

2. EUROSTAT (2010): Income and living conditions in Europe.

3. KSH (2010): Infokommunikációs (IKT-) eszközök és használatuk a háztartásokban, 2009. Budapest.

4. Lelkes O., Medgyesi M., Tóth I. Gy., Ward T. (2009): Income Distribution and the Risk of Poverty. In: European Inequalities: Social Inclusion and Income Distribution in the European Union. Edited by Terry Ward, Orsolya Lelkes, Holly Sutherland, István György Tóth. TÁRKI, Budapest

5. TÁRKI (2010): Jövedelem egyenlötlenség és szegénység Magyarországon 2009. Budapest. 